\title{
Erratum to clinical impact of the lung tissue transcriptome in a teenager with multifocal invasive mucinous adenocarcinoma-a case report
}

\author{
Emma Di Carlo ${ }^{1,2}$, Giuseppe Cipollone ${ }^{3,4}$, Felice Mucilli $^{3,4}$, Carlo Sorrentino $^{1,2}$ \\ ${ }^{1}$ Department of Medicine and Sciences of Aging, ${ }^{2}$ Anatomic Pathology and Immuno-Oncology Unit, Center for Advanced Studies and Technology \\ (CAST), ${ }^{3}$ Department of Medical, Oral and Biotechnological Sciences, "G. d'Annunzio" University of Chieti-Pescara, Chieti, Italy; ${ }^{4}$ General and \\ Thoracic Surgery, "SS Annunziata” Hospital, Chieti, Italy \\ Correspondence to: Prof. Emma Di Carlo, MD, PhD. Anatomic Pathology and Immuno-Oncology Unit, Center for Advanced Studies and Technology \\ (CAST), Via Luigi Polacchi 11, 66100 Chieti, Italy. Email: edicarlo@unich.it.
}

doi: $10.21037 /$ tlcr-2020-18

View this article at: http://dx.doi.org/10.21037/tlcr-2020-18

Erratum to: Transl Lung Cancer Res 2020;9:793-802.

Clinical impact of the lung tissue transcriptome in a teenager with multifocal invasive mucinous adenocarcinoma—a case report

In the June 2020 issue of Translational Lung Cancer Research (TLCR), the case report "Clinical impact of the lung tissue transcriptome in a teenager with multifocal invasive mucinous adenocarcinoma-a case report" (1) was published with one error. On page 794, lines 11-12 of the right column, the transcription factor TTF-1 is incorrectly named "Transcription Termination Factor 1". The name should be corrected as "Thyroid Transcription Factor 1".

The authors regret any inconvenience caused by this error.

Open Access Statement: This is an Open Access article distributed in accordance with the Creative Commons AttributionNonCommercial-NoDerivs 4.0 International License (CC BY-NC-ND 4.0), which permits the non-commercial replication and distribution of the article with the strict proviso that no changes or edits are made and the original work is properly cited (including links to both the formal publication through the relevant DOI and the license). See: https://creativecommons.org/ licenses/by-nc-nd/4.0/.

\section{References}

1. Di Carlo E, Cipollone G, Mucilli F, Sorrentino C. Clinical impact of the lung tissue transcriptome in a teenager with multifocal invasive mucinous adenocarcinoma—a case report. Transl Lung Cancer Res 2020;9:793-802.

Cite this article as: Di Carlo E, Cipollone G, Mucilli F, Sorrentino C. Erratum to clinical impact of the lung tissue transcriptome in a teenager with multifocal invasive mucinous adenocarcinoma-a case report. Transl Lung Cancer Res 2020;9(5):2301. doi: 10.21037/tlcr-2020-18 